\title{
Thrips (Thysanoptera) associated with onion (Allium cepa L.) and Welsh onion (Allium fistulosum L.)
}

\author{
Marta Olczyk*๑, Maria Pobożniak
}

Department of Botany, Physiology and Plant Protection, Faculty of Biotechnology and Horticulture, University of Agriculture in Krakow, 29 Listopada 54, 31-425 Kraków, Poland

\begin{abstract}
We determined the abundance, species composition, sex ratio and seasonal dynamics of thrips on one cultivar of Welsh onion (Allium fistulosum) and eight cultivars of onion (Allium cepa) in South Poland within three vegetation seasons (2014-2016). Nine species of Thysanoptera were identified on A. cepa and A. fistulosum. Irrespective of the onion cultivar, Thrips tabaci was the dominant species (64.4\% of all collected thrips specimens), while Frankliniella intonsa also occurred in high numbers (28.3\%). Conversely, Welsh onion was most often inhabited by $F$. intonsa (62.7\%), although T. tabaci was also numerous (28.3\%). The predatory Aeolothrips intermedius accounted for $4.5 \%$ on A. cepa and $2.9 \%$ on A. fistulosum. In the most numerous species, T. tabaci, F. intonsa and A. intermedius populations were formed mainly by females. The cultivar most colonised by thrips was Kroll of $A$. fistulosum. The tested cultivars of $A$. cepa demonstrated varying degrees of attractiveness to thrips in the subsequent years. The relationship between populations of $T$. tabaci, $F$. intonsa and $A$. intermedius changed in the subsequent months of the growing season. In June, mainly $T$. tabaci and $F$. intons $a$ occurred on onion plants, while from July, the percentage shares of $F$. intonsa and the predatory A. intermedius in the thrips population on many onion cultivars increased. The level of attractiveness of $A$. cepa related to onion thrips, which is reported as a main pest of onion, varies depending on the year and cultivar.
\end{abstract}

Keywords: Aeolothrips intermedius, arrhenotokous, cultivar, Frankliniella intonsa, thelytokous, Thrips tabaci

\section{INTRODUCTION}

Onions have been consumed for thousands of years in various forms in most cultures of the world. They are most commonly used as an aromatic spice and food supplement, but they are also a valuable source of vitamins, minerals, health-promoting substances and essential oils (Dossa et al., 2018). Nowadays, numerous cultivars of onion (Allium cepa L.) are cultivated, from the most popular yellow to red and white onions, as well as the more exquisite Welsh onion (Allium fistulosum L.). Welsh onion is grown mainly for its chives, although the small bulbs are also edible. The largest producers of A. сер $a$ are China, the United States and India, while the production of A. fistulosum is centred in Japan, Korea,
China and Taiwan (Ford-Lloyd and Armstrong, 1993). Among the European Union countries, the leaders in the production and export of onion are Spain, the Netherlands and Poland, while Germany and the Ukraine also have a high onion production (Zaremba, 2015). In Poland, the production of onion amounted to 630,000 and 650,000 tonnes in 2014 and 2016, respectively, while in 2015, due to drought, it fell to 585,000 tonnes. In 2017, the onion production amounted to 667,000 tonnes and was higher compared to next year, when it decreased by $15.6 \%$ to 563,000 tonnes in 2018 (Statistics Poland, 2020). In addition to abiotic factors (water deficiency and temperature), which have a significant impact on onion 
yield, important biotic factors limiting its production include pests and pathogens (Kalbarczyk et al., 2011).

Among the onion pests, one of the most harmful ones is the Thrips tabaci. Larvae and adults of onion thrips live in the leaf sheath and stalk, sucking up the contents of plant cells and causing direct damage, which manifests in the silvering of the leaves and, consequently, inhibited plant growth and reduced bulb weight. In addition, it has indirect effects by promoting the development of fungal and bacterial pathogens as well as the transmission of Iris yellow spot virus (IYSV) (Lewis, 1973). Furthermore, the rapid mass appearance and the high density of thrips on onion crops, particularly during the hot and dry growing seasons, are associated with serious yield loss (Diaz-Montano et al., 2011; Gill et al., 2015). Fournier et al. (1995) demonstrated that in the absence of any control measures, onion thrips infestations of yellow onions resulted in yield losses of $34.5 \%$ and $43 \%$. Similarly, Pandey et al. (2011) reported that onion thrips damaged $90 \%$ of the onion crop in India and $>50 \%$ in the United States (Boateng, 2012). It is also one of the major limiting factors affecting yields of leek (Kucharczyk and Legutowska, 2002), cabbage (Fail and Pénzes, 2004; Trdan et al., 2008a), tomato, pepper, cucumber (Riefler and Koschier, 2009; Ssemwogerere et al., 2013) and peas (Pobożniak et al., 2020). The high potential for a rapid population increase of $T$. tabaci on onion crops is because of a result of their complex lifestyle with a high reproductive rate, a short generation time, a high survival of non-feeding instars (prepupa and pupa), the ability to reproduce without mating (parthenogenesis) and their ability to develop resistance to insecticides (Morse and Hoddle, 2006; Diaz-Montano et al., 2011). Onion thrips do not comprise a homogeneous species and are composed of two distinct reproductive modes: thelytokous and arrhenotokous populations (Nault et al., 2006). The number of generations per year depends on the climatic conditions. In cold areas, from two to three generations may be produced, while in warmer regions, their number can increase up to eight (Gill et al., 2015).

Besides the above-mentioned harmful species T. tabaci, other phytophagous thrips taxa arising from neighbouring crops and wild plants can colonise onion plants. Most of them are not known to cause crop damage (Pobożniak et al., 2007), but their presence on onion plants and sticky traps, which are a useful tool for monitoring onion thrips infestation, can be misleading for farmers. Many authors also observed the presence of Aeolothrips intermedius on onion crops (Pobożniak et al., 2007; Mautino et al., 2014; Pobożniak et al., 2016), and this predatory taxa reduces the densities of other thrips populations and is a predator of 44 species of the Thysanoptera order (Riudavetes, 1995), potentially controlling onion thrips (Trdan et al., 2005). Accurate identification of thrips pests is fundamental to their effective control. Knowledge of this insect pest biology and seasonal dynamics would allow establishing control strategies in a future Integrated Pest Management (IPM) programme.
In this context, this study aimed to determine thrips abundance, species composition and seasonal fluctuation on eight cultivars of $A$. сеpa and one cultivar of $A$. fistulosum. We also assessed the entity of the autochthonous predator A. intermedius, which is a potential biological control agent of T. tabaci.

\section{MATERIALS AND METHODS}

Field and laboratory research on the determination of composition, abundance and significance of particular thrips species was conducted in the Department of Botany, Physiology and Plant Protection of the University of Agriculture in Krakow, Poland.

\section{Plant material}

All onion cultivars of $A$. cepa used in the experiment were obtained from three Polish seed breeding companies: PlantiCo Zielonki in Stare Babice (cv. Alibaba with white bulb, cv. Bila, Kristine, Niagra $F_{1}$ with yellow bulb and cv. Wenta with red bulb), Polan in Krakow (cv. Karmen with red and cv. Polanowska with yellow bulb) and Spójnia in Nochowo (cv. Tęcza with yellow bulb). The cultivar Kroll, the only cultivar of the Welsh onion A. fistulosum (with white bulb), was obtained from PlantiCo Zielonki in Stare Babice.

\section{Study area}

In the years 2014-2016, field experiments were conducted at the Experimental Station of the University of Agriculture in Krakow, located in Mydlniki (near Krakow, southern Poland, $50^{\circ} 04^{\prime} \mathrm{N}, 19^{\circ} 51^{\prime} \mathrm{E}, 207 \mathrm{~m}$ above sea level) on a typical brown soil with $\mathrm{pH} 6.5$ and an organic carbon content of $18 \mathrm{~g} \cdot \mathrm{kg}^{-1}$. The experiment was established using the method of random blocks in four replications. The size of the experimental plots was $12 \mathrm{~m}^{2}\left(3 \times 4 \mathrm{~m}^{2}\right)$, with a distance of $1 \mathrm{~m}$ between the plots. Seeds were sown $\left(25 \mathrm{~kg} \cdot \mathrm{ha}^{-1}\right)$ in rows, 0.3 apart, on 6th April 2014, 10th April 2015 and 6th April 2016. The experimental plots were fertilised according to the Integrated Production recommendations for onions in the field. The plots were kept free of weeds throughout the season. No chemical treatments were carried out on the plots during the experiment, and weeding was performed manually. The crops that surrounded the experimental plot were as follows: potatoes, herbs, red beets, white cabbage, zucchini and pumpkin; additionally, sunflowers and ornamental plants, such as marigold and dahlia, grew in the near surroundings. At a distance of about $0.5 \mathrm{~km}$ from the experimental site, cereals and rape were grown.

\section{Entomological analyses}

In the three successive years (2014-2016), the period of entomological analyses lasted from the second decade of June to the end of August. In 2014, analyses were performed at intervals of 14 days, while in 2015 and 2016, analyses were performed weekly, between 10:00 am and 3:00 pm on sunny days. Sampling 
thrips consisted of two methods: thrips collected with sweeping net and the method composed of plant bagging in plastic bags and then analysis in the laboratory. Thrips landing and spreading on plants were gathered in the net, while the second method allowed collecting of specimens hidden under folded leaves and near the base of the bulb. Thrips were collected from onion leaves using a standard entomological sweeping net $(35 \mathrm{~cm}$ in diameter). Within each testing plot, 25 sweeps were made, and the sweeping nets and samples were placed individually into plastic bags. In parallel to the sweeping net analysis, 10 randomly selected plants from each plot (40 plants for cultivar) were collected and placed in plastic bags, followed by appropriate labelling. The collected material was transported to the laboratory, where insects were hand-separated using a soft brush and thrips were placed in vials containing $75 \%$ ethyl alcohol. Because the species complex of thrips and percentage share from net and direct counting from harvested plants were the same or similar (Tables S1 and S2 in Supplementary Materials), specimens collected by both methods from the same plots and date are shown combined in Tables 1-4 and Figures 1-3.

\section{Identification of thrips species}

Microscopic slides were prepared under laboratory conditions according to the technique described by Zawirska (1994). The specimens (adults and immature) were identified to species rank with the use of a microscope, following the keys of Zawirska (1994), Zur Strassen (2003) (adults) and Kucharczyk (2010) (larvae).

\section{Sex ratio}

The sex ratio (the percentage of females in a population) was calculated using the standard sex ratio formula as presented below (Vasiliu-Oromulu, 2002):

$$
S r=f:(m+f) \times 100,
$$

where $S r$ is the sex ratio, $f$ is the number of females (imago) and $m$ is the number of males (imago).

\section{Statistical analysis}

Statistical analyses were performed using the Statistica 13 software (Dell Inc. 2016). In the case of lack of normality, the data were normalised with $\log (x+1)$ transformation. Tables and figures contain untransformed data. One-way analysis of variance (ANOVA; the factor was onion cultivar) was performed for the data, i.e. mean number of thrips. Differentiation of the mean values was determined based on Tukey's HSD (honestly significant difference) test $(p<0.05)$.

\section{RESULTS}

\section{Abundance and composition of species}

In 2014, during the field study, 3,791 thrips belonging to six species were identified in the collected material from the different onion cultivars (Table 1). A significantly higher number of thrips was recorded on Welsh onion cv. Kroll (932 individuals) $(F=3.531, p<0.006)$ compared with five other cultivars of onion: Wenta, Alibaba, Karmen, Bila and Niagara $F_{1}$, with 349 to 310 specimens on cv. Wenta and Niagara $\mathrm{F}_{1}$, respectively (Table 1).

The most abundant species on Welsh onion (cv. Kroll) was Frankliniella intonsa (flower thrips) (86.48\%); in turn, T. tabaci predominated on onion cultivars. In cultivars of $A$. cepa, thrips accounted for $78.75 \%$ (cv. Karmen) to $45.60 \%$ (cv. Kristine) of the total number of collected thrips specimens. Of the tested onion cultivars, those most inhabited by onion thrips were cv. Tęcza and Polanowska, while the least colonised cultivar was Kristine. The number of T. tabaci infested Welsh onion (cv. Kroll) plants was low and almost 1.8 times smaller than the least populated onion cultivar. The third species in terms of the number of individual thrips collected was the predatory $A$. intermedius. Its share in the collected material ranged from $1.22 \%$ on cv. Tęcza to $7.74 \%$ on cv. Niagara $\mathrm{F}_{1}$; the other three species Thrips flavus, Haplothrips aculeatus and Haplothrips leucantemi accounted for only $2.48 \%$ of the total number of thrips (Table 1).

In 2015, 19,450 individuals, belonging to nine species, were identified (Table 2). The highest number of thrips was found on Welsh onion cv. Kroll (4,536 specimens) in comparison to each onion cultivar $(F=9.995, p<0.000)$. With regard to $A$. cepa, significant differences in the number of collected thrips were found only between cv. Karmen (2,439 individuals) and cv. Polanowska (1,475 individuals) (Table 2). In all the collected material from both Allium species, from three (cv. Tęcza) to eight (cv. Bila and Niagara $F_{1}$ ) species of thrips were identified. The most numerous species on all onion cultivars was onion thrips, with a total number of individuals of $10,257(68.89 \%)$, while this taxa was second in terms of the number of individuals collected from Welsh onion (39.26\%). The share of T. tabaci in the collected material from tested A. серa cultivars was from $64.97 \%$ (cv. Tęcza) to $73.77 \%$ (cv. Wenta). In 2015 , the cultivar most inhabited by onion thrips was the Welsh onion cv. Kroll, followed by the cultivars Karmen and Tęcza, both from A. cepa. Similar to the previous year, flower thrips constituted the most abundant taxa registered on cv. Kroll (2,687 specimens), accounting for $59.24 \%$ of the collected material from A. fistulosum. From all tested cultivars of $A$. серa, 4,260 specimens of $F$. intonsa were collected, comprising $28.62 \%$ of all thrips. The highest percentage share of this species was detected on cv. Tęcza (33.31\%) and the smallest was on cv. Wenta (24.27\%). Of the species A. intermedius, we collected 368 individuals, accounting for $0.88 \%$ (cv. Kroll) to $2.88 \%$ (cv. Kristine) of the total species. Only $0.49 \%$ of the total number of thrips constituted the other six species. In addition to species that had been identified in the previous year, we also registered Thrips fuscipennis, Chirothrips hamatus and Haplothrips niger (Table 2). 


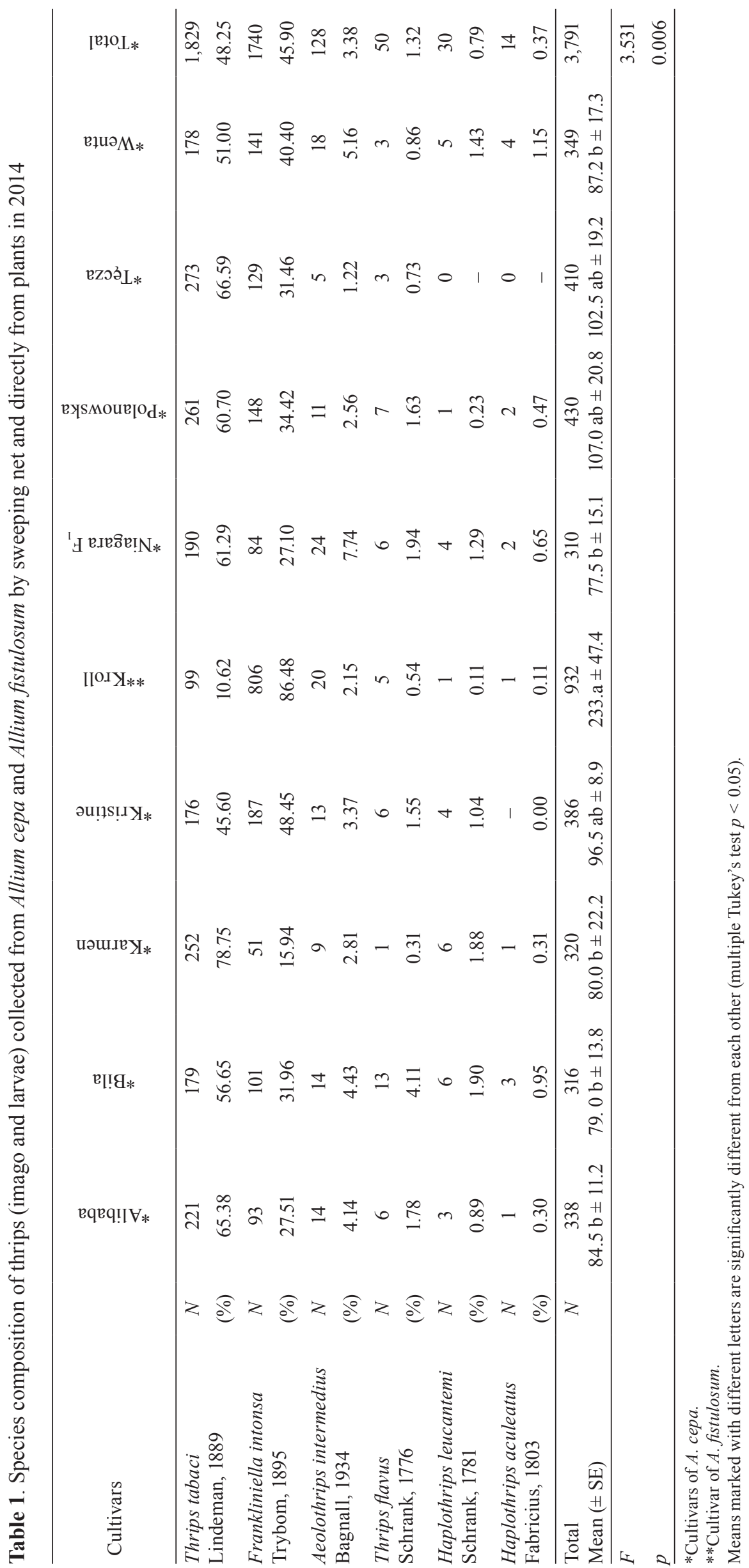




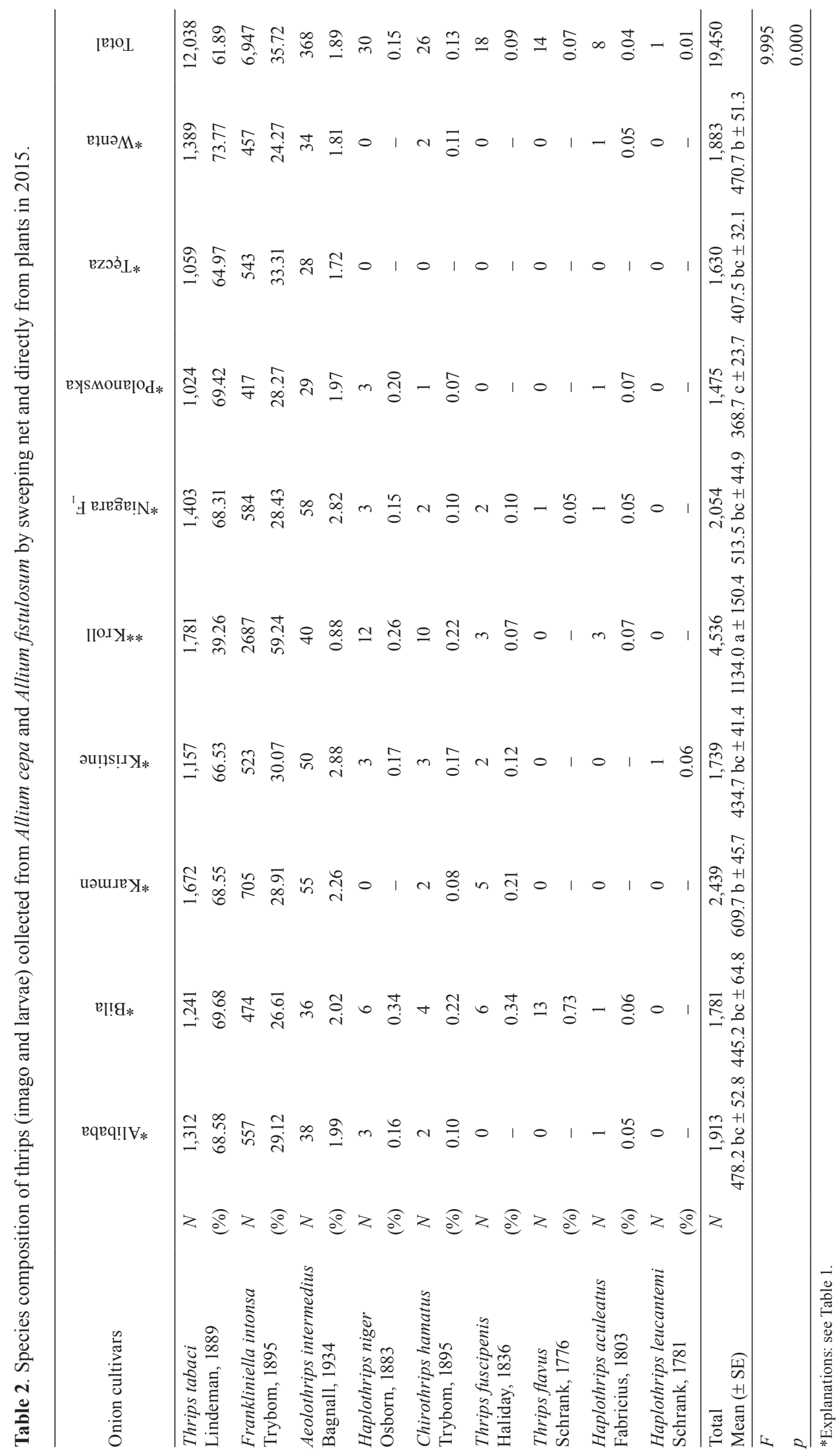




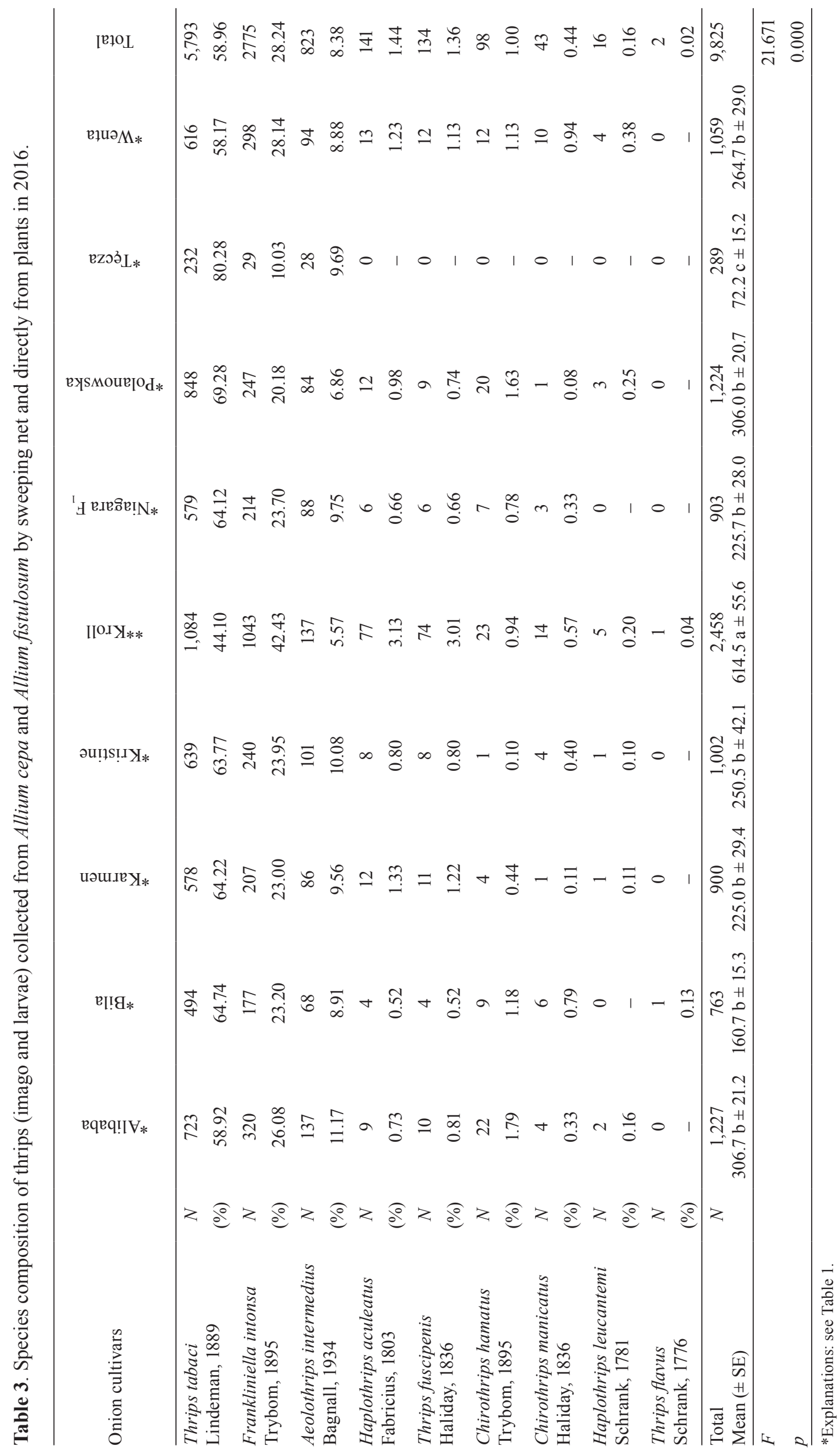


Table 4. Sex ratio index of the most numerous species of thrips (imago) collected from Allium cepa and Allium fistulosum by sweeping net and directly from plants in 2015 and 2016.

\begin{tabular}{|c|c|c|c|c|c|c|c|c|c|}
\hline \multirow[t]{2}{*}{ Onion cultivars } & \multicolumn{3}{|c|}{ Thrips tabaci } & \multicolumn{3}{|c|}{ Aeolothrips intermedius } & \multicolumn{3}{|c|}{ Frankliniella intonsa } \\
\hline & Male & Female & Sex ratio & Male & Female & Sex ratio & Male & Female & Sex ratio \\
\hline \multicolumn{10}{|l|}{2015} \\
\hline Alibaba & 1 & 1,311 & 99.9 & 1 & 37 & 97.4 & 15 & 542 & 97.3 \\
\hline Bila & 14 & 1,227 & 98.9 & 0 & 36 & 100.0 & 11 & 463 & 97.7 \\
\hline Karmen & 20 & 1,652 & 98.8 & 4 & 51 & 92.7 & 15 & 690 & 97.9 \\
\hline Kristine & 2 & 1,155 & 99.8 & 0 & 50 & 100.0 & 12 & 511 & 97.7 \\
\hline Kroll** & 12 & 1,769 & 99.3 & 5 & 35 & 87.5 & 81 & 2606 & 97.0 \\
\hline Niagara $F_{1}$ & 15 & 1,388 & 98.9 & 0 & 58 & 100.0 & 21 & 563 & 96.4 \\
\hline Polanowska & 0 & 1,024 & 100.0 & 2 & 27 & 93.1 & 14 & 403 & 96.6 \\
\hline Tęcza & 0 & 1,059 & 100.0 & 0 & 28 & 100.0 & 0 & 543 & 100.0 \\
\hline Wenta & 0 & 1,389 & 100.0 & 3 & 31 & 91.2 & 5 & 452 & 98.9 \\
\hline \multicolumn{10}{|l|}{2016} \\
\hline Alibaba & 0 & 723 & 100.0 & 33 & 104 & 75.9 & 3 & 317 & 99.1 \\
\hline Bila & 0 & 494 & 100.0 & 18 & 50 & 73.5 & 2 & 175 & 98.9 \\
\hline Karmen & 1 & 577 & 99.8 & 18 & 68 & 79.1 & 1 & 206 & 99.5 \\
\hline Kristine & 1 & 638 & 99.8 & 22 & 79 & 78.2 & 2 & 238 & 99.2 \\
\hline Kroll** & 0 & 1,084 & 100.0 & 21 & 116 & 84.7 & 21 & 1,022 & 98.0 \\
\hline Niagara $F_{1}$ & 1 & 578 & 99.8 & 25 & 63 & 71.6 & 0 & 214 & 100.0 \\
\hline Polanowska & 2 & 846 & 99.8 & 18 & 66 & 78.6 & 1 & 246 & 99.6 \\
\hline Tęcza & 0 & 232 & 100.0 & 0 & 28 & 100.0 & 0 & 29 & 100.0 \\
\hline Wenta & 0 & 616 & 100.0 & 23 & 71 & 75.5 & 7 & 291 & 97.7 \\
\hline
\end{tabular}

**Cultivar of A. fistulosum, other cultivars are the A. cepa.

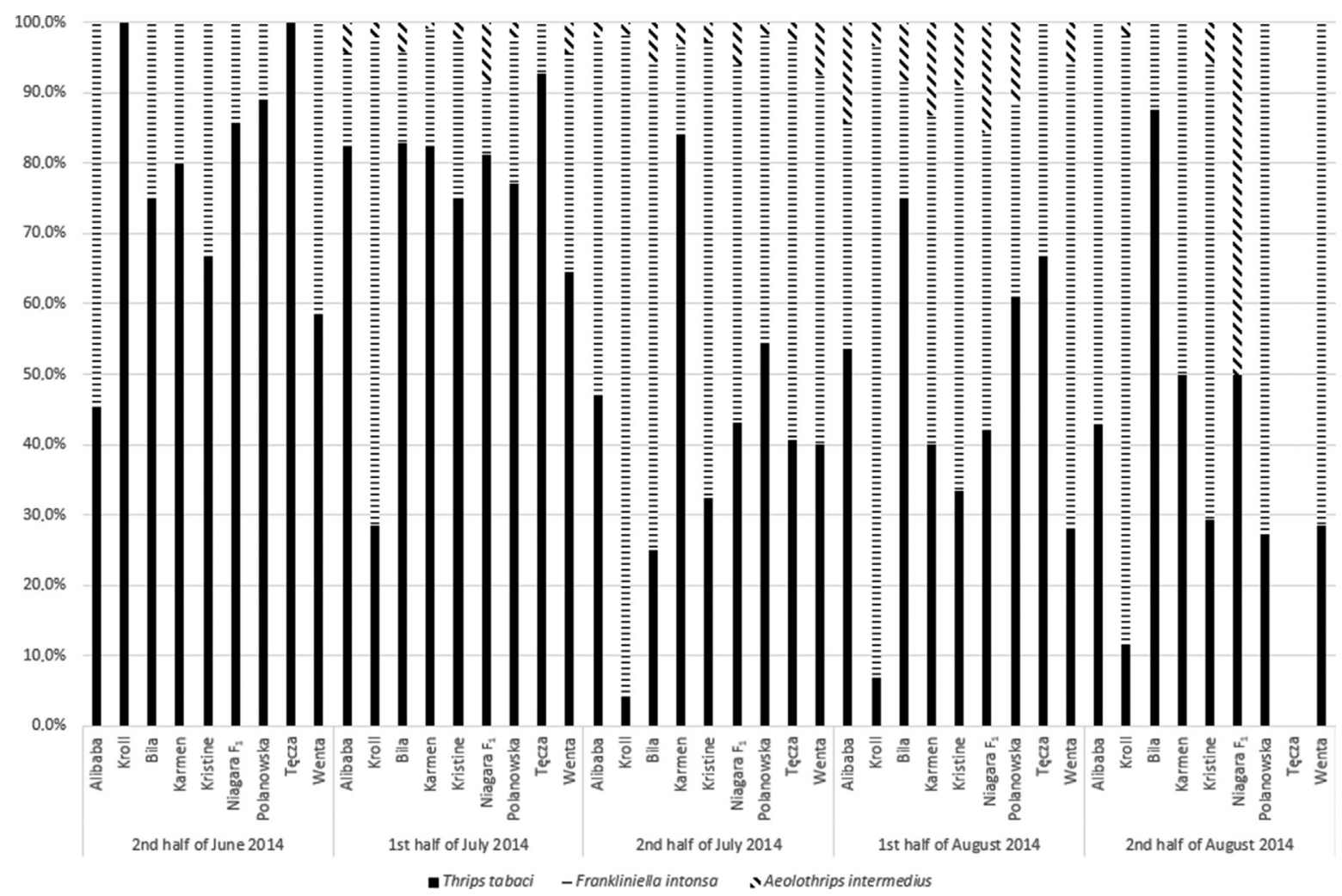

Figure 1. Share of the three most abundant species on Allium cepa and Allium fistulosum in 2014 (cv. Kroll - A. fistulosum, others cvs - A. серa). 


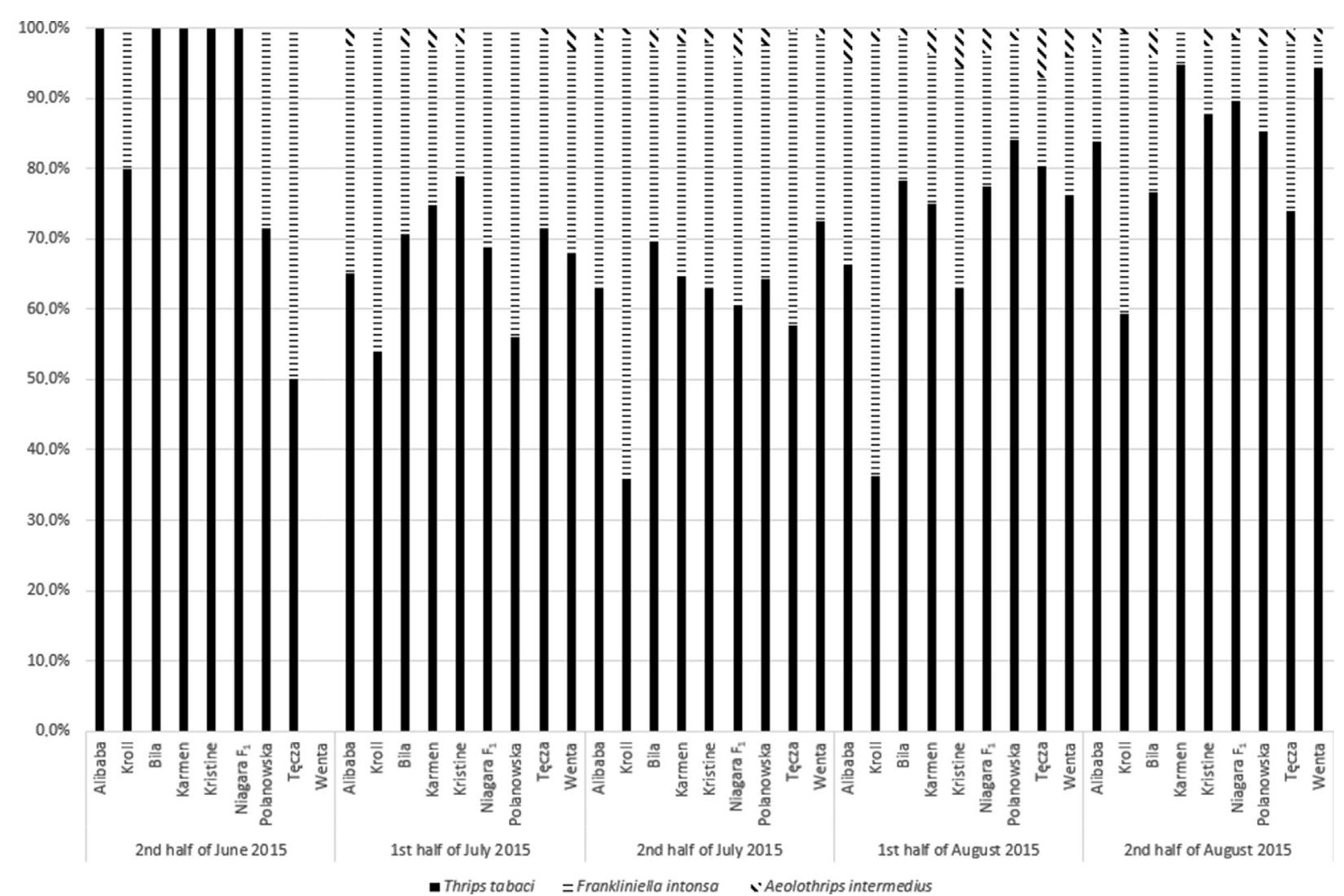

Figure 2. Share of the three most abundant species on Allium cepa and Allium fistulosum in 2015 (cv. Kroll A. fistulosum, others cvs - A. cepa).

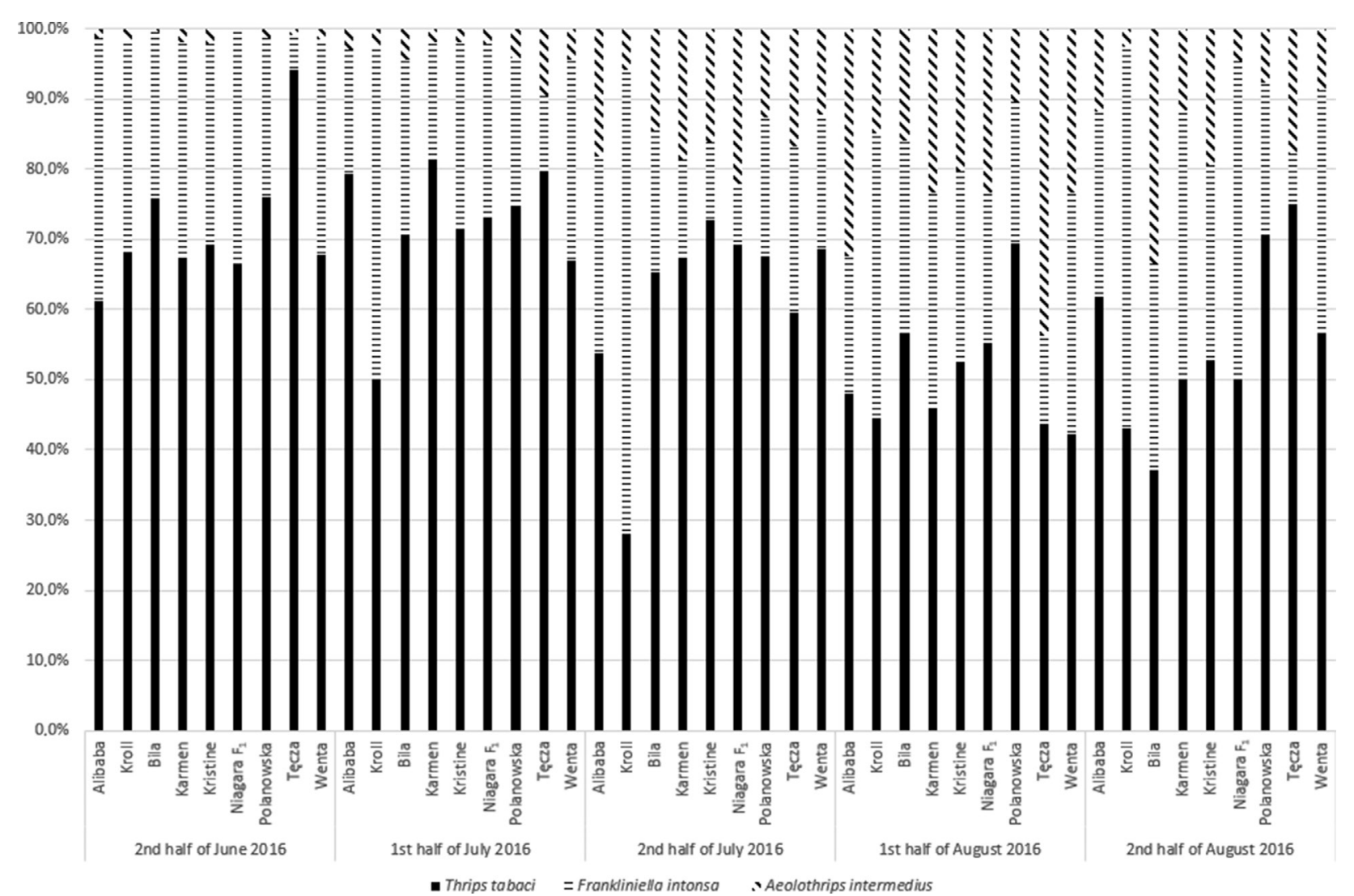

Figure 3. Share of the three most abundant species on Allium cepa and Allium fistulosum in 2016 (cv. Kroll A. fistulosum, others cvs - A. cepa). 
In 2016, a total of 9,825 individuals of thrips, belonging to nine species, inhabited Welsh onion and onion plants. The highest number of thrips was found on the Welsh onion cv. Kroll (2,458 specimens) $(F=21.671$, $p<0.000$; Table 3), while the lowest number of thrips was observed on the onion cv. Tęcza (289 individuals). Among the cultivars of $A$. cepa, thrips were most abundant on the cultivars Alibaba (1,227 specimens) and Polanowska (1,224 thrips) (Table 3). Irrespective of the number of thrips individuals collected from cultivars of A. cepa, the number of detected thrips species ranged from seven to eight, except for cv. Tęcza, where only three species were noted. The insects collected from cv. Kroll represented nine thrips species. The most abundant species on all tested onion cultivars and Welsh onion was onion thrips, with a total number of 5,793 individuals (58.96\%). Its share on A. серa cultivars ranged from $58.17 \%$ on cv. Wenta to $80.28 \%$ on cv. Tęcza, while on cv. Kroll, it reached $44.10 \%$. Of the onion cultivars, the most inhabited one was cv. Polanowska, while the least was cv. Tęcza. The second most abundant species was F. intonsa with 2,775 specimens, accounting for $28.24 \%$. Its percentage share was the highest on cv. Kroll $(42.43 \%)$, while on the other cultivars, it did not exceed $28.14 \%$ (cv. Wenta). The third highest percentage share in terms of the number of individual thrips collected in 2016 was found for $A$. intermedius with 823 individuals, accounting for $8.38 \%$ (from $5.57 \%$ on cv. Kroll to $11.17 \%$ on cv. Alibaba). Similar to the previous years, the other six species only accounted for $4.42 \%$ of the total species (Table 3).

The comparisons of thrips complex and percentage share of species caught by both sampling methods are presented in Tables 1 and 2. Within 3 years (2014-2016), much more specimens were collected directly from sweeping $(18,228$ specimens from onion and 6,814 from Welsh onion) than during a direct counting of specimens from harvested plants (respectively, 6,898 and 1,126 specimens from onion and Welsh onion). The complex of dominant species gathered with net and directly from onion and Welsh onion plants was the same and there were little differences between both the methods in the case of accessory species in 2015 and 2016. In 2014, the share of $T$. tabaci caught with sweeping was greater than that collected by direct counting thrips from onion and Welsh onion plants, while in the next 2 years the opposite ratio was noticed in the total collection of sampled thrips from onion and in 2015 from Welsh onion. The share of $F$. intonsa and A. intermedius was higher in material collected by direct counting thrips from onion in 2014, while in the next 2 years it was higher in the material gathered in net. In material collected from Welsh onion, the share of $F$. intonsa in net was higher within 2014 and 2015, while the ratio of A. intermedius was higher in net only in 2015. In turn in 2016, the share of three dominated species was nearly the same in material gathered by both methods from Welsh onion.

\section{Sex ratio index of the most abundant three species}

The population of T. tabaci was mainly represented by females. In 2015, 64 males were collected from five cultivars of onion (cv. Alibaba, Bila, Karmen, Kristine and Niagara $F_{1}$ ) and from Welsh onion (cv. Kroll). The numbers ranged from 1 specimen on cv. Alibaba to 20 thrips on cv. Karmen. The calculated sex ratio collected from these cultivars ranged from $98.8 \%$ (cv. Karmen) to $99.9 \%$ (cv. Alibaba). In 2016, only single males were found on cv. Karmen, Kristine, Niagara $F_{1}$ and Polanowska, and the sex ratio was $99.8 \%$ in all cultivars (Table 4).

In the population of $F$. intonsa, males occurred in greater numbers. In both years of research, males were registered on all tested cultivars except only on cv. Niagara $F_{1}$ in 2016 and Tęcza in both years. Larger numbers of $F$. intonsa males (174 specimens) were caught in 2015, when the overall abundance of thrips was high. In 2016, we registered only 37 males of flower thrips. In both years, most males were caught from A. fistulosum (cv. Kroll), which was the cultivar most infested by this species. Its sex ratio on this cultivar was $97 \%$ in 2015 and $98 \%$ in 2016. On cultivars of A. cepa, the sex ratio of $F$. intonsa was similar on all cultivars and ranged from $96.4 \%$ to $98.9 \%$ in 2015 and from $97.7 \%$ to $99.6 \%$ in 2016 (Table 4 ).

In contrast to $T$. tabaci and $F$. intonsa, males of predatory A. intermedius were less numerous in 2015, and only single individuals (from two to four) were collected from four cultivars of A. cepa (Alibaba, Karmen, Polanowska and Wenta) and five males from cv. Kroll (A. fistulosum). Its mean sex ratio on A. cepa was 93.6\%, while on A. fistulosum, it was $87.5 \%$ (Table 4). In 2016, from all cultivars infested by A. intermedius, 178 males were collected; the mean sex ratio was $76.05 \%$ on cultivars of A. cepa and $84.7 \%$ on cv. Kroll of A. fistulosum (Table 4).

\section{Seasonal fluctuation of the most abundant three species}

The seasonal fluctuations of T. tabaci, F. intonsa and $A$. intermedius throughout the three growing seasons (2014-2016) are shown in Figures 1-3.

As shown in Figure 1, in June, among the most numerous species $T$. tabaci and $F$. intonsa, the percentage share of onion thrips on cultivars of $A$. cepa ranged from $45.5 \%$ (cv. Alibaba) to $100 \%$ (cv. Tęcza). In turn, cv. Kroll (A. fistulosum) was at that time only colonised by T. tabaci. In the first half of July, T. tabaci was the dominant species on all tested cultivars of A. cepa, while on A. fistulosum, the dominant species was $F$. intonsa, accounting for $69.4 \%$. From mid-July to the end of August, T. tabaci accounted for $25.0-87.5 \%$ on the onion cultivars, while its share on Welsh onion was low and did not exceed $11.5 \%$. The predatory A. intermedius was recorded from the beginning of 
June, and its percentage share on all tested cultivars ranged from $1.7 \%$ to $15.8 \%$. Only in the second half of August, its share on cv. Niagara $F_{1}$ was much higher and amounted to $50.0 \%$.

In June 2015, most of the tested onion cultivars were colonised only by $T$. tabaci, with the exception of cv. Polanowska, Tęcza and Kroll, on which this species accounted for $71.4 \%, 50.0 \%$ and $80.0 \%$, respectively (Figure 2). In July (especially in the second half), the share of $F$. intonsa increased on $A$. cepa from $18.4 \%$ (cv. Kristine) to $44.0 \%$ (cv. Polanowska) and to $63.5 \%$ on A. fistulosum. In August, in all cultivars of A. cepa, the ratio of the number of both species was reversed, and T. tabaci was again the most abundant taxon. On A. fistulosum, the share of onion thrips was $36.2 \%$ and $59.4 \%$, respectively, in the first and second half of August. Similar to the previous year, A. intermedius was caught from the beginning of July to the end of August, mostly from all tested cultivars, and in July, its share in the collected material did not exceed $4.2 \%$, while in August it reached $7.0 \%$ (Figure 2).

In June 2016, T. tabaci occurred in greater percentages on all tested cultivars (from $61.3 \%$ on cv. Alibaba to $94.1 \%$ on cv. Tęcza) (Figure 3). This species was also most abundant in July and constituted $>50 \%$, except on the cv. Kroll. In August, its percentage share of $A$. cepa ranged from $37.0 \%$ (cv. Bila) to $75.0 \%$ (cv. Tęcza). The share of $F$. intonsa was the highest on A. fistulosum, and in the second half of July, it was as high as $65.9 \%$. From mid-July, an increase in the $A$. intermedius percentage was noticed, with the highest level on the cv. Tęcza in the first half of August (43.8\%) (Figure 3).

\section{DISCUSSION}

The obtained results indicate that A. fistulosum and A. cepa plants are colonised by six to nine thrips species throughout the growing season, primarily by the suborder Terebrantia and the family Thripidae. Two herbivorous (T. tabaci and $F$. intonsa) and one predatory (A. intermedius) species together accounted for over 97\% of the material collected from onion and Welsh onion plants throughout 3 years. T. tabaci was the most abundant species on all tested cultivars of onion, the second most numerous was $F$. intonsa, while the opposite ratio was noticed on Welsh onion. The participation of thrips species differed by years and both species of Allium. The mean share of T. tabaci in the total collection of sampled thrips from $A$. серa ranged from $60.5 \%$ to $68.8 \%$, while for $F$. intonsa it was lower and accounted from $23.5 \%$ to $32.7 \%$. In turn, in material collected from A. fistulosum, the share of onion thrips ranged from $10.6 \%$ to $44.1 \%$, while for flower thrips it accounted from $42.4 \%$ to $86.4 \%$. Also, Pobożniak et al. (2016) found that the population of T. tabaci in onion crops may vary depending on the year, and the share of this species on onions crops can range from $34 \%$ to $68 \%$, while for $F$. intonsa, it can range from $29.8 \%$ to $58.0 \%$. Onion thrips predominated, accounting for $82.6 \%$ to $84.9 \%$ of the thrips on onion in Colorado (USA) (Mahaffey and Cranshaw, 2010). In Texas (USA), according to Bender and Morrison (1989) and Doederlein and Sites (1993), the species composition of thrips on onion is dominated by the western flower thrips (Frankliniella occidentalis Pergande) and by onion thrips. Sparks et al. (2011) reported that key arthropod pests on onions in Georgia (USA) are tobacco thrips (Frankliniella fusca Hinds), western flower trips and onion thrips, which represented $49.9 \%$ of all detected thrips. The species T. tabaci is a major pest and predominant on onion fields in Europe (Hudák and Pénzes, 2004; Diaz-Montano et al., 2011; Gill et al., 2015; Pobożniak et al., 2016), the United States (Macintyre-Allen et al., 2005, Smith et al., 2016), Asia (Pandey et al., 2011; Reitz et al., 2011; Li et al., 2014), Australia (Herron et al., 2008), New Zealand (Martin et al., 2006) and Africa (Maniania et al., 2003). In addition to onion, onion thrips may attack garlic and leek (Afifi and Haydar, 1990; Theunissen and Schelling, 1998; Duchovskienė, 2006; Akhtari et al., 2014) and other vegetables, such as cauliflower, cabbage, pea, cucumber and carrot (Farrugia, 1997; Pourian et al., 2009; Li et al., 2014, Pobożniak et al., 2020; Silva et al., 2020). Notably, the extent and frequency by which onion thrips damage crops vary across plant species, but onion is its preferred host and the most damaged crop. Also, $F$. intons a has been determined in Poland on the onion by Pobożniak et al. (2016) and on leek by Legutowska and Theunissen (2003). This species is mainly associated with flowering plants and is the dominant species in legume field crops such as peas, beans, soybeans, lentils and lupine in Poland (Pobożniak, 2011; Hurej et al., $2014 ; 2015)$. There is no information in the literature on the possibility of $F$. intonsa feeding on onion plants. The author's own observations, however, suggest that this species is not likely to feed on onion, and the presence of $F$. intonsa specimens on onion at least partially may be due to the presence of many flowering plants in the vicinity of the experimental plots. However, Hazir et al. (2011) discussed the possibility of this species feeding on organs other than the flowers. The authors report that $F$. intonsa feeding on ovary tissue caused brown blemishes and scars on nectarine fruit, and feeding on mature fruit caused whitish skin patches called silvering. Also, Murai (1988) noted that swollen white spots were produced as a result of this species feeding on tomato fruits. Moreover, Molnár et al. (2008) observed that in addition to $T$. tabaci and $F$. occidentalis also $F$. intonsa feeds on pepper and can also spread the tomato spotted wilt virus (TSWV) with the same efficacy as the other two species. The very high abundance of $F$. intonsa on onion and the observations of the cited authors indicate a potential possibility of this species feeding also on onions, but this issue requires further clarification.

The predatory $A$. intermedius was a less abundant species and accounting for about $4.5 \%$ of all species on A. cepa and $2.9 \%$ on A. fistulosum. Similarly, Pobożniak et al. (2016) found about $5 \%$ of $A$. intermedius on Allium sp. The appearance of this predatory thrips species 
was noticed on A. fistulosum in Ljubljana (Trdan et al., 2005). In turn, Ábrahám (2012) observed about 9\% of this taxon on alfalfa, and Pobożniak et al. (2020) registered about $8.6 \%$ on peas, with the first maximum appearance during the flowering and the second during forming pods phases, when the number of potential victim, onion thrips, was the highest. The occurrence of A. intermedius in the flowers of many plants may be due to the fact that pollen can be used as an alternative source of food by this species (Trdan et al., 2005; Conti, 2009). In Europe, $A$. intermedius has usually been mentioned as a predator of onion thrips (Franco et al., 1999). In our experiment, the percentage share of predatory thrips increased on the onion plants from mid-July. In our opinion, A. intermedius certainly limited the number of onion thrips on onion plants. However, despite its presence, the numbers of herbivorous onion thrips were so high that they caused damage to the onion leaves. Also, Pobożniak et al. (2020) and Ábrahám (2008) noted that the number of A. intermedius was insufficient to reduce the population of phytophagous thrips in pea and soybean. Other species associated with flowers (Thrips flavus, Thrips fuscipenis, Haplothrips leucantemi and Haplothrips niger) and mainly with grasses (Chirothrips hamatus, Chirothrips manicatus and Haplothrips aculeatus) were observed on A. cepa and A. fistulosum in a small numbers. They have also been found in small amounts on onion by Pobożniak et al. (2007), on leek by Legutowska and Theunissen (2003) and on cabbage by Fail and Pénzes (2004) and their presence was accidental and resulted from the neighbourhood of flowering plants and cereals.

The species T. tabaci can reproduce asexually (parthenogenesis) and sexually. The most common reproductive mode is thelytoky, a parthenogenesis in which females are produced from unfertilised eggs. Onion thrips also reproduce via arrhenotoky, a parthenogenesis in which males are produced from unfertilised eggs and females from fertilised eggs. Onion thrips that reproduce via thelytoky differ genetically and ecologically from those that reproduce via arrhenotoky (Toda and Murai, 2007). According to Kobayashi et al. (2013), in some instances, arrhenotokous and thelytokous onion thrips populations can coexist in the same field, but it is difficult to distinguish between thelytokous and arrhenotokous female adults morphologically (Jenser and Szénási, 2004). On onion, arrhenotokous T. tabaci performed better than thelytokous form and produced more progenies, while on cabbage, the opposite occurred (Li et al., 2014). In our experiment, both females and males of T. tabaci were found on $A$. cepa and A. fistulosum, and the average sex ratio on all tested onion cultivars was about $99.5 \%$ and $99.9 \%$ in 2015 and 2016, respectively, and $99.3 \%$ and $100 \%$ on Welsh onion in subsequent years. Different sex ratios on onions crops, garlic and leeks have also been confirmed by Torres-Vila et al. (1994) in Spain. Both females and males of T. tabaci were found also by Bosco and Tavella (2010) on leek under field conditions in northwest Italy. In the Netherlands, the male/female ratio of onion thrips on leek was 1:26 (Vierbergen and Ester, 2000). In turn, in Ontario (USA), Macintyre-Allen et al. (2005) did not notice the presence of $T$. tabaci males on onion crops. According to Jenser and Szénási (2004), the rare occurrence or absence of male T. tabaci is associated with the geographical area from which the host plants originate, including onions and leeks. Their area of origin is Central Asia and the eastern Mediterranean region; T. tabaci has been introduced in moderate climate zones, which is likely to explain the absence of males (Jenser and Szénási 2004).

In the case of $F$. intonsa, the average sex ratio on onion cultivars and Welsh onion was nearly the same and accounted for $97.8 \%$ and $97.0 \%$ on $A$. cepa and $97.0 \%$ and $98.0 \%$ on A. fistulosum in 2015 and 2016, respectively (Table 4). In a population of $F$. intonsa in flowers of food legume plants, participation of males was even higher, with a sex ratio of over $79 \%$ Pobożniak (2011). Hurej et al. (2015), in their analysis of thrips settlement on both forms of Andean lupine, pointed out that in the case of flower thrips, the morphological form of the plant did not affect the occurrence of male thrips, and the calculated sex ratio was $86.2 \%$.

Mautino et al. (2014) noted that the adult population of $A$. intermedius consists of both female and male zoophages. In our experiment, the sex ratio of this species on A. cepa and A. fistulosum was about $96.8 \%$ and $79.0 \%$ on onion and about $87.5 \%$ and $84.7 \%$ on Welsh onion in 2015 and 2016, respectively (Table 4). Hurej et al. (2017) reported that the sex ratio of A. intermedius on linseed ranged from $61.5 \%$ to $77.1 \%$, but never exceeded $80 \%$. In turn, on peas, beans, lentil, French beans or soya beans, the percentage of males in the population of $A$. intermedius was lower, and the sex ratio ranged from $82.4 \%$ to $89.6 \%$ (Pobożniak, 2011).

The relationship between populations of the most numerous species $T$. tabaci, $F$. intonsa and $A$. intermedius changed in the subsequent months of the growing season. In June 2014 and 2015, only T. tabaci and $F$. intonsa occurred on onion plants, while in 2016, also a small number of the predatory $A$. intermedius was observed. From July, the percentage shares of $F$. intonsa and predatory A. intermedius in the thrips populations on many onion cultivars increased, most likely because of the presence of many flowering plants near the experimental plots and the growing population of T. tabaci on onion plants, potential A. intermedius prey. Pobożniak et al. $(2007 ; 2016)$ reported that the peak flight activity of thrips on onion crops in South Poland took place from the beginning of July to the beginning of August and was slightly earlier than that reported for Germany (Richter et al., 1999). In turn, in North Italy, the peak population of onion thrips was reached in September (Bosco and Tavella, 2010), while in South Texas (USA), it peaked in April (Liu, 2004).

Differences in the infestation levels of thrips between the all tested onion cultivars were observed in successive years. In all 3 years of the study, the cultivar most populated by thrips specimens was cv. Kroll (A. fistulosum), on which the number of $F$. intonsa was 
8 and 1.5 times as high compared to T. tabaci in 2014 and 2015 , respectively, while the numbers of both species in 2016 were similar. The number of thrips caught from the $A$. cepa cultivars was about from 2 to 3 times lower compared to the thrips population on Welsh onion (cv. Kroll). However, the number of T. tabaci on cultivars of $A$. cepa was always higher than that of $F$. intonsa. In the case of some cultivars, the number of $T$. tabaci was even about 3, 5 or 8 times as high compared to $F$. intonsa or was almost the same. In turn, Pobożniak et al. (2016) found that in some years, onion thrips inhabited Welsh onion more frequently compared to onion cultivars. The tested onion cultivars demonstrated varying degrees of attractiveness to thrips species and underwent changes in the subsequent years. The level of attractiveness of onion cultivars related to T. tabaci, which is reported as a main pest of onion, varied depending on the year and cultivar. The differences in thrips infestation of the studied cultivars are caused by a number of factors, and clarifying them requires further research. Presumably, factors affecting the colonisation of cultivars by $T$. tabaci were their biochemical and morphological features, influencing the vision, taste and smell senses of thrips, and could be responsible for antixenosis and antibiosis (Smith, 2005; Trdan et al., 2008b; Diaz-Montano et al., 2012; Silva et al., 2014).

\section{CONCLUSIONS}

1. In the 3 years of the study, nine species of Thysanoptera were identified on $A$. cepa and A. fistulosum. Irrespective of the cultivar of $A$. cepa, T. tabaci was the most dominant species, but $F$. intonsa also occurred in high numbers. Conversely, A. fistulosum was most often inhabited by $F$. intonsa, although $T$. tabaci was also highly abundant. The predatory $A$. intermedius was among the most numerous species.

2. Of the most numerous species, T. tabaci and $F$. intonsa, in each cultivar of $A$. cepa and A. fistulosum, populations were formed mainly by females. In the population of $A$. intermedius, males occurred in greater numbers than in the two previously mentioned species.

3. The relationship between populations of the most numerous species T. tabaci, F. intonsa and $A$. intermedius changed in the subsequent months of the growing season. In June, mainly $T$. tabaci and $F$. intonsa occurred on onion plants, while from July, the percentage shares of $F$. intons $a$ and the predatory A. intermedius in the thrips population on many onion cultivars increased. Throughout the experimental period, the onion cultivar most colonised by thrips was cv. Kroll of $A$. fistulosum in comparison to all tested cultivars of $A$. серa. The tested cultivars of $A$. cepa demonstrated varying degrees of attractiveness to thrips in the subsequent years.

4. The level of attractiveness of A. cepa related to onion thrips, which is reported as a main pest of onion, varies depending on the year and cultivar. The cultivars with higher colonisation rates were Polanowska and Karmen, while the less populated ones were cvs. Tęcza, Bila and Kristine.

\section{FUNDING}

This research was supported by the Ministry of Science and Higher Education of Poland as a part of research subsidy to the University of Agriculture in Kraków.

\section{AUTHOR CONTRIBUTIONS}

M.O. and M.P. contributed equally to the experimental design, analytical measurements and manuscript writing.

\section{CONFLICT OF INTEREST}

The authors declare no conflict of interest.

\section{REFERENCES}

ÁBrahÁm, R. (2008). Thrips species associated with soybean in Hungary. Acta Phytopathologica et Entomologica Hungarica, 43(2), 211-218.

ÁBrAнÁm, R. (2012). First investigation of species composition of Thysanoptera inhabiting alfalfa based on their second stage larvae. Acta Phytopathologica et Entomologica Hungarica, 47(1), 81-86.

Afifi, F. M. L., and Haydar, M. F. (1990). Effect of different intercropping systems on onion and garlic infestation with the 'cotton and onion thrips', Thrips tabaci Lind. Bulletin of Faculty of Agriculture University of Cairo, 41(3), 639-648.

Akhtari, M., Dashti, F., Madadi, H., and Rondon, S. (2014). Evaluation of resistance to onion thrips (Thrips tabaci Lind.) in several Tareh Irani (Persian leek: Allium ampeloprasum Tareh group) landraces. Archives of Phytopathology and Plant Protection, 47(1), 29-41.

Bender, D. A., And Morrison, W. P. (1989). Species composition and control of thrips in Texas high plains onions. Journal of Agricultural Entomology, 6(4), 257-263.

Bonteng, C. O. (2012). Physiological responses of onion germplasms to Iris yellow spot virus and onion thrips (Thrips tabaci). PhD dissertation, Colorado State University, Fort Collins, CO, USA, pp. 326.

Bosco, L., And Tavella, L. (2010). Population dynamics and integrated pest management of Thrips tabaci on leek under field conditions in northwest Italy. Entomologia Experimentalis et Applicata, 135(3), 276-287.

Conti, B. (2009). Notes on the presence of Aeolothrips intermedius in north western Tuscany and on its development under laboratory conditions. Bulletin of Insectology, 62, 107-112. 
Da Silva, V. C. P., Bettoni, M. M., Bona, C., And Foerster, L. A. (2014). Morphological and chemical characteristics of onion plants (Allium cepa L.) associated with resistance to onion thrips. Acta Scientiarum, Agronomy, 37(1), 85-92.

Dell Inc. (2016). Dell Statistica (data analysis software system), version 13. software.dell.com.

Diaz-Montano, J., Fail, J., Deutschlander, M., Nault, B. A., And Shelton, A. M. (2012). Characterization of resistance, evaluation of the attractiveness of plant odors, and effect of leaf colour on different onion cultivars to onion thrips (Thysanoptera: Thripidae). Journal of Economic Entomology, 105(2), 632-641.

Diaz-Montano, J., Fuchs, M., Nault, B. A., Fail, J., And Shelton, A. M. (2011). Onion thrips (Thysanoptera: Thripidae): A global pest of increasing concern in onion. Journal of Economic Entomology, 104(1), $1-13$.

Doederlein, T. A., And Sites, R. W. (1993). Host plant preferences of Frankliniella occidentalis and Thrips tabaci (Thysanoptera: Thripidae) for onions and associated weeds on the Southern High Plains, Journal of Economic Entomology, 86(6), 1706-1713.

Dossa, F., Miassi, Y., and Banzou, K. (2018). Onion (Allium cepa) production in urban and peri-urban areas: financial performance and importance of this activity for market gardeners in Southern Benin. Current Investigations in Agriculture and Current Research, 3(2), 1-13.

Duchovskiené, L. (2006). The abundance and dynamics of onion thrips (Thrips tabaci Lind.) in leek under field conditions. Agronomy Research, 4, 163-166.

FAIL, J., AND PÉnZes, B. (2004). Species composition of Thysanoptera in white cabbage heads. Acta Phytopathologica et Entomologica Hungarica, 39(1), 165-171.

FARrugia, C. (1997). Insect pests on cauliflower (Brassica oleracea var. botrytis) in Gozo (Maltese Islands, Central Mediterranean). The Central Mediterranean Naturalist, 2(4), 152-165.

Ford-Lloyd, B. V., AND Armstrong, S. J. (1993). Welsh onion: Allium fistulosum L. In G. Kalloo and B. O. Bergh (Eds), Genetic improvement of vegetable crops (pp. 51-58). Oxford, UK: Pergamon Press.

Fournier, F., Boivin, G., And Stewart, R. K. (1995). Effect of Thrips tabaci (Thysanoptera: Thripidae) on yellow onion yields and economic thresholds for its management. Journal of Economic Entomology. 88(5), 1401-1407.

Franco, S., Beignet, P., Rat, E., and Thibout, E. (1999). The effects of thrips on wild and cultivated alliaceous plants in France. Phytoma La Defense des Vegetaux, 514, 41-44.

Gill, H. K., Garg, H., Gill, A. K., Gillett-Kaufman, J. L., AND Nault, B. A. (2015). Onion thrips (Thysanoptera: Thripidae) biology, ecology, and management in onion production systems. Journal of Integrated Pest Management, 6(1), 1-9.
Hazir, A., Rifat, M., Ulusoy, M., and Atakan, E. (2011). Studies on determination of Thysanoptera species associated with nectarines and their damage in Adana and Mersin provinces, Turkey. Turkish Journal of Entomology, 35(1), 133-144.

Herron, G. A., James, T. M., And Mo, J. H. (2008). Australian populations of onion thrips, Thrips tabaci Lindeman (Thysanoptera: Thripidae), are resistant to some insecticides used for their control. Australian Journal of Entomology, 47, 361-364.

HudÁk, K., ANd PÉNZes, B. (2004). Factors influencing the population of the onion thrips on onion. Acta Phytopathologica et Entomologica Hungarica, 39(1), 193-197.

Hurej, M., Kucharczyk, H., Twardowski, J. P., And Kotecki, A. (2015). Thrips (Thysanoptera) associated with two morphological forms of Andean lupin (Lupinus mutabilis), Biologia, 70(7), 935-942.

Hurej, M., Kucharczyk, H., Twardowski, J. P., And Kotecki, A. (2017). Thrips (Thysanoptera) associated with two genetically modified types of linseed (Linum usitatissimum L.). Journal of Plant Diseases and Protection, 124, 81-91.

Hurej, M., Kucharczyk, H., Twardowski, J. P., And KozaK, M. (2014). Thrips (Thysanoptera) associated with narrow-leafed lupin (Lupinus angustifolius L., 1753) intercropped with spring triticale (X Triticosecale Wittm. Ex A. Camus, 1927). Romanian Agricultural Research, 31, 337-345.

JenSER, G., AND SzÉNÁSI, Á. (2004). Review of the biology and vector capability of Thrips tabaci Lindeman (Thysanoptera: Thripidae), Acta Phytopathologica et Entomologica Hungarica, 39(1), 137-155.

Kalbarczyk, E., KalbarczyK, R., and Raszka, B. (2011). Risk to onion (Allium cepa L.) field cultivation in Poland from precipitation deficiency. Notulae Botanicae Horti Agrobotanici Cluj-Napoca, 39(2), 214-218.

Kobayashi, K., Yoshimura, J., and Hasegawa, E. (2013). Coexistence of sexual individuals and genetically isolated asexual counterparts in a thrips. Scientific Reports, 3, 3286, doi: 10.1038/srep03286.

KucharczyK, H. (2010). Comparative morphology of the second larval instar of the Thrips genus species (Thysanoptera: Thripidae) occurring in Poland. Olsztyn, Poland: Mantis Publishing Press.

KucharczyK, H., and Legutowska, H. (2002). Thrips tabaci as a pest of leek cultivated in different conditions. Paper presented at the Thrips and Tospoviruses: $7^{\text {th }}$ International Symposium on Thysanoptera, Gallina, Reggio Calabria, Italy, 211-213.

Legutowska, H., And Theunissen, J. (2003). Thrips species in leeks and their under sown intercrops. IOBC/WPRS Buletin, 26(3), 177-182.

LEwIS, T. (1973). Thrips their biology, ecology and economic importance. London, UK: Academic Press. 
Li, X. W., Fail, J., Wang, P., Feng, J. N., And Shelton, A. M. (2014). Performance of arrhenotokous and thelytokous Thrips tabaci (Thysanoptera: Thripidae) on onion and cabbage and its implications on evolution and pest management. Journal of Economic Entomology, 107(4), 1526-1534.

LiU, T. X. (2004). Seasonal population dynamics, life stage composition of Thrips tabaci (Thysanoptera: Thripidae), and predaceous natural enemies on onions in south Texas. Southwestern Entomologist, 29, 127-135.

Macintyre-Allen, J. K., Scott-Dupree, C. D., Tolman, J. H., AND Harris, C. R. (2005). Evaluation of sampling methodology for determining the population dynamics of onion thrips (Thysanoptera: Thripidae) in Ontario onion fields. Journal of Economic Entomology, 98(6), 2272-2281.

Mahaffey, L. A., And Cranshaw, W. S. (2010). Thrips species associated with onion in Colorado. Southwestern Entomologist, 35(1), 45-50.

Maniania, N. K., Sithanantham, S., Ekesi, S., AmpongNyarko, K., Baumgärtner, J., LÖHr, B., AND MatokA, C. M. (2003). A field trial of the entomogenous fungus Metarhizium anisopliae for control of onion thrips, Thrips tabaci Crop Protection, 22(3), 553-559.

Martin, N., Workman, P., And Hedderley, D. (2006). Monitoring onion crops for onion thrips Thrips tabaci. New Zealand Plant Protection, 59, 69-74.

Mautino, G. C., Bosco, L., And Tavella, L. (2014). Impact of control strategies on Thrips tabaci and its predator Aeolothrips intermedius on onion crops. Phytoparasitica, 42, 41-52.

Molnár, A., PAP, Z., And Fail, J. (2008). Observing population changes of thrips (Thysanoptera) species damaging forced pepper and their natural enemie. International Journal of Horticultural Science, 14(4), 55-60.

Morse, J. G., And Hoddle, M. S. (2006). Invasion biology of thrips. Annual Review of Entomology, 51, 67-89.

Murai, T. (1988). Studies on the ecology and control of flower thrips, Frankliniella intonsa (Trybom). Bulletin of the Shimane Agricultural Experiment Station, 23, 1-73.

Nault, B. A., Shelton, A. M., Gangloff-Kaufmann, J. L., Clark, M. E., Werren, J. L., and Cabrera-LA Rosa, J. C. (2006). Reproductive modes in onion thrips (Thysanoptera: Thripidae) populations from New York onion fields. Environmental Entomology, 35, 1264-1271.

Pandey, S., Mishra, R. K., and Singh, S. K. (2011). Studies on entomopathogenic fungus for management of onion thrips to produce quality onion. Biopesticides International, 7, 165-167.

PobożniaK, M. (2011). The occurrence of thrips (Thysanoptera) on food legumes (Fabaceae). Journal of Plant Diseases and Protection, 118(5), 185-193.

Pobożniak, M., LeŚniak, M., Chuda, A., and Adamus, A. (2016). Field assessment of the susceptibility of onion cultivars to thrips attack-preliminary results. Polish Journal of Entomology, 85, 121-133.

Pobożniak, M., Palacz, A., and Rataj, A. (2007). The occurrence and species composition of thrips (Thysanoptera) on onion. Communications in Agricultural and Applied Biological Sciences, 72(3), 487-493.

PobożniaK, M., ToKarz, K., And Musynov, K. (2020). Evaluation of sticky trap colour for thrips (Thysanoptera) monitoring in pea crops (Pisum sativum L.). Journal of Plant Diseases and Protection, 127, 307-321.

Pourian, H., Mirab-Balou, M., Alizadeh, M., And Orosz, S. (2009). Study on biology of onion thrips, Thrips tabaci Lindeman (Thysanoptera: Thripidae) on cucumber (var. Sultan) in laboratory conditions. Journal of Plant Protection Research, 49(4), 390-394.

Reitz, S. R., GaO, Y. L., AND LeI, Z. R. (2011). Thrips: Pests of concern to China and the United States. Agricultural Sciences in China, 10(6), 867-892.

Richter, E., Hommes, M., and Krauthausen, J. H. (1999). Investigation on the supervised control of Thrips tabaci in leek \& onion crops. IOBC/WPRS Bulletin, 22(5), 61-72.

Riefler, J., And Koschier, E. H. (2009). Comparing behavioural patterns of Thrips tabaci Lindeman on leek and cucumber. Journal of Insect Behavior, 22(2), 111-120.

Riudavetes, J. (1995). Predators of Frankliniella occidentalis (Perg.) and Thrips tabaci Lind.: A review. In A. J. M. Loomans, J. C. van Lenteren and M. G. Tommasini (Eds) Biological control of thrips pest (pp. 43-87). Wageningen Agricultural University Papers 95.1.

Silva, R. V., Teixeira, A. B., Diniz, J. F. S., Plata-Rueda, R. A., Lima, É. F. B., And Fernandes, F. L. (2020). First record of thrips species and their damage to carrot in Alto Paranaíba. Brazilian Journal of Biology, 80(1), 194-196.

Smith, E. A., Shields, E. J., And Nault, B. A. (2016). Onion thrips colonization of onion fields bordering crop and non-crop habitats in muck cropping systems. Journal of Applied Entomology, 141(7), 574-582.

Smith, M. C. (2005). Plant resistance to arthropods. Dordrecht, The Netherlands: Springer.

Sparks, A. N., Diffie, S., and Riley, D. G. (2011). Thrips species composition on onions in the Vidalia Production Region of Georgia. Journal of Entomological Science, 46(1), 40-45.

Ssemwogerere, C., Kathrynn, M., Ochwo-Ssemakula, M., Kovach, J., Kyamanywa, S., and Karungi, J. (2013). Species composition and occurrence of thrips on tomato and pepper as influenced by farmers' management practices in Uganda. Journal of Plant Protection Research, 53(2), 158-164.

STATISTICS POLAND, 2020. Statistical Yearbook of Agriculture. Retrieved from https://stat.gov.pl. 
Theunissen, J., And Schelling, G. (1998). Infestation of leek by Thrips tabaci as related to spatial and temporal patterns of undersowing. BioControl, 43, 107-119.

Toda, S., And Murai, T. (2007). Phylogenetic analysis based on mitochondrial COI gene sequences in Thrips tabaci Lindeman (Thysanoptera: Thripidae) in relation to reproductive forms and geographic distribution. Applied Entomology and Zoology, 42(2), 309-316.

Torres-Vila, L. M., Lacasa, A., Bielza, P., and Meco, R. (1994). Dinámica poblacional de Thrips tabaci Lind. (Thysanoptera: Thripidae) sobre liliáceas hortícolas en Castilla-La Mancha. Boletín de Sanidad Vegetal Plagas, 20(2), 661-677.

Trdan, S., Anduus, L., Raspudić, E., And Kač, M. (2005). Distribution of Aeolothrips intermedius Bagnall (Thysanoptera: Aeolothripidae) and its potential prey Thysanoptera species on different cultivated host plants. Journal of Pest Science, 78, 217-226.

Trdan, S., Valič, N., Andjus, L., Vovk, I., Martelanc, M., Simonovska, B., Jerman, J., Vidrih, R., Vidrih, M., AND ŽNIDRAČIČ, D. (2008b). Which plant compounds influence the natural resistance of cabbage against onion thrips (Thrips tabaci Lindeman)? Acta Phytopathologica et Entomologica Hungarica, 43(2), 385-395.

Trdan, S., ŽnidArČıč, D., KAČ, M., AND Matej, V. (2008a). Yield of early white cabbage grown under mulch and non-mulch conditions with low populations of onion thrips (Thrips tabaci Lindeman). International Journal of Pest Management, 54(4), 309-318.

Vasiliu-Oromulu, L. (2002). The dynamics of the sex ratio index of thrips populations in mountainous meadows. Paper presented at the Thrips and Tospoviruses: Proceedings of the $7^{\text {th }}$ International Symposium on Thysanoptera, Australian National Insect Collection, Canberra.

Vierbergen, G., AND Ester, A. (2000). Natural enemies and sex ratio of Thrips tabaci (Thysanoptera: Thripidae), a major pest of Allium porrum in the Netherlands. Mededelingen - Faculteit Landbouwkundige en Toegepaste Biologische Wetenschappen, Universiteit Gent, 65(2a), 335-342.

ZAREMBA, Ł. (2015). Polish onion production and export in the European Union market background. Stowarzyszenie Ekonomistów Rolnictwa i Agrobiznesu, Roczniki Naukowe, XVII(5), 348-352.

Zawirska, I. (1994). Thrips (Thysanoptera), In M. W. KOZŁOWSKI AND J. BOCZEK (Eds), Diagnostics of plant pests and their natural enemies (pp. 145-174). Warsaw, Poland: SGGW.

Zur Strassen, R. (2003). Die Terebranten Thysanopteren Europas. Keltern, Germany: Die Tierwelt Deutschlands, 74 Teils. Goecke and Evers.

Received: June 17, 2020; accepted: October 29, 2020. 


\section{SUPPLEMENTARY MATERIALS}

Table S1. Total number and percentage share of thrips species (Thysanoptera) (imago and larvae) collected from Allium cepa (mean \% for eight tested cultivars) and Allium fistulosum (one cultivar) directly from plants in 2014-2016.

\begin{tabular}{|c|c|c|c|c|c|c|c|c|c|}
\hline \multirow[t]{3}{*}{ Species/year } & \multicolumn{6}{|c|}{ A. сера } & \multicolumn{3}{|c|}{ A. fistulosum } \\
\hline & \multicolumn{2}{|l|}{2014} & \multicolumn{2}{|c|}{2015} & \multicolumn{2}{|c|}{2016} & 2014 & 2015 & 2016 \\
\hline & Min-max* & Mean & Min-max & Mean & Min-max & Mean & \multicolumn{3}{|c|}{ Mean } \\
\hline $\begin{array}{l}\text { Thrips tabaci } \\
\text { Lindeman, } 1889\end{array}$ & $38.24-61.19$ & 51.23 & $71.96-81.50$ & 78.35 & $71.53-81.30$ & 76.45 & 20.11 & 49.92 & 40.20 \\
\hline $\begin{array}{l}\text { Frankliniella intonsa } \\
\text { Trybom, } 1895\end{array}$ & $16.54-41.26$ & 32.17 & $16.38-25.18$ & 19.84 & $3.5-20.05$ & 19.36 & 72.06 & 49.20 & 44.64 \\
\hline $\begin{array}{l}\text { Aeolothrips intermedius } \\
\text { Bagnall, } 1934\end{array}$ & $1.42-19.17$ & 9.69 & $0.46-2.31$ & 1.49 & $1.75-3.50$ & 3.73 & 5.46 & 0.48 & 6.14 \\
\hline $\begin{array}{l}\text { Chirothrips hamatus } \\
\text { Trybom, } 1895\end{array}$ & - & - & $0.00-0.28$ & 0.10 & $0.00-0.57$ & 0.10 & - & 0.20 & 1.11 \\
\hline $\begin{array}{l}\text { Chirothrips manicatus } \\
\text { Haliday, } 1836\end{array}$ & - & - & - & - & $0.00-0.41$ & 0.07 & - & - & 0.69 \\
\hline $\begin{array}{l}\text { Haplothrips aculeatus } \\
\text { Fabricius, } 1803\end{array}$ & $0.00-2.13$ & 1.51 & $0.00-0.17$ & 0.05 & $0.00-0.99$ & 0.23 & - & - & 3.55 \\
\hline $\begin{array}{l}\text { Haplothrips leucantemi } \\
\text { Schrank, } 1781\end{array}$ & $0.00-3.57$ & 1.41 & - & 0.03 & - & - & 0.52 & - & 0.22 \\
\hline $\begin{array}{l}\text { Haplothrips niger } \\
\text { Osborn, } 1883\end{array}$ & - & - & $0.00-0.15$ & - & - & - & - & 0.20 & - \\
\hline $\begin{array}{l}\text { Thrips flavus } \\
\text { Schrank, } 1776\end{array}$ & $0.00-9.75$ & 3.99 & - & - & - & - & 1.85 & - & 0.06 \\
\hline $\begin{array}{l}\text { Thrips fuscipenis } \\
\text { Haliday, } 1836\end{array}$ & - & - & $0.00-0.46$ & 0.14 & $0.00-0.31$ & 0.06 & - & - & 3.39 \\
\hline Total number & - & 629 & - & 3999 & - & 2270 & 153 & 659 & 314 \\
\hline
\end{tabular}

*Min-mean percentage of thrips on onion cultivar with the lowest percentage share; max-mean percentage of thrips on onion cultivar with the highest percentage share. 
Table S2. Total number and percentage share of thrips species (Thysanoptera) (imago and larvae) collected from Allium cepa (mean\% for eight tested cultivars) and Allium fistulosum (one cultivar) using sweeping net in 2014-2016.

\begin{tabular}{|c|c|c|c|c|c|c|c|c|c|}
\hline \multirow[t]{3}{*}{ Species/Year } & \multicolumn{6}{|c|}{ A. сера } & \multicolumn{3}{|c|}{ A. fistulosum } \\
\hline & \multicolumn{2}{|c|}{2014} & \multicolumn{2}{|c|}{2015} & \multicolumn{2}{|c|}{2016} & 2014 & 2015 & 2016 \\
\hline & Min-max* & Mean & Min-max & Mean & Min-max & Mean & \multicolumn{3}{|c|}{ Mean } \\
\hline $\begin{array}{l}\text { Thrips tabaci } \\
\text { Lindeman, } 1889\end{array}$ & $46.63-78.91$ & 63.60 & $60.58-70.40$ & 65.08 & $47.54-74.36$ & 60.68 & 10.69 & 37.90 & 40.19 \\
\hline $\begin{array}{l}\text { Frankliniella intonsa } \\
\text { Trybom, } 1895\end{array}$ & $14.31-49.64$ & 31.58 & $27.08-37.92$ & 32.04 & 7.70-17.09 & 22.09 & 87.49 & 60.82 & 44.63 \\
\hline $\begin{array}{l}\text { Aeolothrips intermedius } \\
\text { Bagnall, } 1934\end{array}$ & $14.31-49.64$ & 2.44 & $27.08-37.92$ & 2.36 & 7.86-17.09 & 12.85 & 1.38 & 1.02 & 6.69 \\
\hline $\begin{array}{l}\text { Chirothrips hamatus } \\
\text { Trybom, } 1895\end{array}$ & - & - & $0.10-0.31$ & 0.11 & $0.00-2.39$ & 1.36 & - & 0.01 & 1.01 \\
\hline $\begin{array}{l}\text { Chirothrips manicatus } \\
\text { Haliday, } 1836\end{array}$ & - & - & - & - & $0.00-1.89$ & 0.64 & - & - & 0.69 \\
\hline $\begin{array}{l}\text { Haplothrips aculeatus } \\
\text { Fabricius, } 1803\end{array}$ & $0.00-1.78$ & 0.22 & $0.00-0.25$ & 0.03 & $0.00-1.71$ & 1.08 & 0.13 & 0.08 & 3.55 \\
\hline $\begin{array}{l}\text { Haplothrips leucantemi } \\
\text { Schrank, } 1781\end{array}$ & $0.00-2.40$ & 1.19 & - & - & $0.00-0.42$ & 0.20 & - & - & 0.24 \\
\hline $\begin{array}{l}\text { Haplothrips niger } \\
\text { Osborn, } 1883\end{array}$ & - & - & $0.47-1.02$ & 0.72 & - & - & - & 0.1 & - \\
\hline $\begin{array}{l}\text { Thrips flavus } \\
\text { Schrank, } 1776\end{array}$ & $0.31-2.12$ & 0.97 & $0.00-0.76$ & 0.10 & $0.00-0.21$ & 0.03 & 0.31 & - & 0.06 \\
\hline $\begin{array}{l}\text { Thrips fuscipenis } \\
\text { Haliday, } 1836\end{array}$ & - & - & $0.00-0.28$ & 0.07 & $0.00-1.61$ & 1.07 & - & 0.07 & 2.23 \\
\hline Total number & - & 2230 & - & 10901 & - & 5097 & 779 & 3891 & 2144 \\
\hline
\end{tabular}

*Min-mean percentage of thrips on onion cultivar with the lowest percentage share; max-mean percentage of thrips on onion cultivar with the highest percentage share. 